\title{
EVALUASI KINERJA MODEL PAGE PADA PENGERINGAN LAPISAN TIPIS UMBI ILES-ILES
}

\section{(The Evaluation of Page Model Performance on Thin Layer Drying of Iles-Iles Roots)}

\author{
Mukmin $^{* 1)}$, Junaedi Muhidong ${ }^{1)}$, dan Abdul Azis ${ }^{1)}$ \\ ${ }^{1)}$ Program Studi Teknik Pertanian Universitas Hasanuddin \\ ${ }^{*}$ email korespondensi: mukmin@gmail.com
}

\begin{abstract}
The iles-iles is an umber plant having a high economic potential. This plant can only grow in tropical and subtropical areas. This study aims to evaluating the accuracy of the page model in estimating the moisture ratio of the iles-iles in the form of slice during the thin layer drying process. This research uses $45^{\circ} \mathrm{C}$ and $55^{\circ} \mathrm{C}$ drying temperature as well as the thickness of iles-iles $1,0 \mathrm{~cm}$ and $0,5 \mathrm{~cm}$. Drying air velocity was used at $1,0 \mathrm{~m} / \mathrm{s}$. The observation parameters used on this study were the weight of the sample and the drying time. Results of this study are the water-level drop pattern, moisture ratio drop pattern, the value of page model drying, and page model evaluations. Those results describe that the relation between the predictive value and the observation value of moisture ratio create regression equations without the intersept with $\mathrm{R}^{2}$ approaching value. Consequently, the acquired page model is preferred to give partial predictions of iles-iles. Meanwhile the $\mathrm{R}^{2}$ value is 0.998 , the chi-squared, value is $5.202 \times 10^{2}$, and the RMSE value is. The concise of $\mathrm{R}^{2}$, Chi-Squared, and RMSE with the previous research had relatively small value that indicated that a page model drying performance on the study was also quite good.
\end{abstract}

Keywords: Iles-Iles, Thin Layer Drying, Page Model.

\begin{abstract}
ABSTRAK
Tanaman iles-iles (Amorphophallus muelleri) merupakan jenis umbi-umbian dengannilaipotensial ekonomi yang cukuptinggi. Tanaman ini hanya dapat tumbuh di daerah tropis dan subtropis.Penelitian ini dimaksudkan untuk mengevaluasi keakuratan model Page dalam menduga moisture ratio umbi iles-iles (Amorphophallus muelleri)yang berbentuk irisan selama proses pengeringan lapisan tipis. Penelitian dilakukan dengan menggunakan suhu pengeringan $45^{\circ} \mathrm{C}$ dan $55{ }^{\circ} \mathrm{C}$ dengan ketebalan sampel iles-iles $1.0 \mathrm{~cm}$ dan $0.5 \mathrm{~cm}$. Kecepatan udara pengeringan digunakan sebesar $1.0 \mathrm{~m} / \mathrm{s}$. Parameter pengamatan yang digunakan berat sampel selama proses pengeringan dan waktu pengeringan. Sehingga diperoleh hasil seperti pola penurunan kadar air, pola penurunan moisture rasio, nilai konstanta pengeringan Model Page, dan evaluasi kinerja Model Page yang menggambarkan hubungan antara nilai prediksi dan nilai observasi moisture ratio yg menghasilkan persamaan regresi tanpa intersept dengan nilai $\mathrm{R}^{2}$ yang mendekati 1.0, maka Model Page yang diperoleh dianggap baik dalam melakukan prediksi moisture ratio umbi iles-iles. Adapun nilai $\mathrm{R}^{2}$ yaitu 0.998 , nilai Chi-squared yaitu $5.202 \times 10^{-2}$ dan nilai $\mathrm{RMSE}$ yaitu 0.006 . Selisih nilai $\mathrm{R}^{2}$, Chi-squared, dan RMSE antara berbagai penelitian yg dilakukan terdahulu dengan penelitian ini yg relatif sangat kecil mengindikasikan bahwa kinerja Model Page pada penelitian ini juga cukup baik.
\end{abstract}

Kata Kunci: Iles-Iles, Pengeringan Lapisan Tipis, Model Page. 


\section{PENDAHULUAN}

\section{Latar Belakang}

Tanaman iles-iles (Amorphophallus muelleri) merupakan jenis tanaman umbi-umbian dengan nilai potensial ekonomi yang cukup tinggi tinggi. Tanaman ini tumbuh di daerah tropis dan sub-tropis. Di Indonesia sendiri, tanaman ini belum belum dilirik secara ekonomis sehingga hanya dibiarkan tumbuh secara liar. Tanaman iles-iles dapat digunakan sebagai tanaman pangan alternative selain beras dengan kandungan karbohidrat tinggi. Namun diperlukan proses pengolahan sebelum dikomsumsi karena kristal oksalat yang menyebabkan gatal.

Umbi iles-iles memiliki nilai yang tinggi dan diminati dipasar internasional seperti Jepang, Malaysia dan Singapura. Kurangnya minat petani dalam menanam tanaman iles-iles ini dikarenakan rendahnya nilai jual ditingkat petani yang berkisar $\mathrm{Rp}$ 9000/Kg. Hal ini berbeda dengan di Jepang yang harganya dapat mencapai $\mathrm{Rp} 60.000 / \mathrm{Kg}$ setelah melalui proses-proses pasca panen. Perbedaan yang tinggi ini disebabkan belum adanya proses pasca panen secara signifikan ditingkat petani.

Bagian padatanaman iles-iles yang digunkana dalam pembuatan tepung adalah bagian umbinya. Umbi iles-iles memiliki kadar air yang tinggi sehingga diperlukan pengeringan untuk menghindari kerusakan akibat mikroba. Pengeringan dapat dilakukan dengan dua cara yaitu pengeringan secara alami dan pengeringan secara buatan. Pengeringan merupakan penurunan kadar air sampai batas tertentu dengantujuan menghambat laju kerusakan suatu bahan akibat aktivitas biologis dan kimia sebelum bahan diolah. Salah satu tujuan dalam pengeringan yaitu mengurangi kadar air dengan menguapkan air tersebut baik secara alami dengan memanfaatkan cahaya matahari atau dengan menggunakan alat pengering.

Penanganan pasca panen iles-iles ditingkat petani masih dilakukan secara tradisional, pengeringan iles-iles dilakukan dengan penjemuran menggunakan sinar matahari sehingga memerlukan waktu yang lama. Keterlambatan pengeringan dapat berdampak buruk terhadap mutu bahan yang dihasilkan. Kadar air iles-iles segar sekitar $80 \%$ basis basah (Irene, 2010). Kadar air ini termasuk tinggi dan memerlukan pengeringan sehingga kadar airnya aman untuk penyimpanan. Pengeringan lapisan tipis merupakan langkah awal untuk memahami proses pengeringan dengan volume yang lebih besar.

Ada beberapa model matematika yang dapat digunakan untuk melihat perilaku suatu komoditas pertanian selama proses pengeringan lapisan tipis. Model-model tersebut antara lain model Newton, Henderson-Pabis dan Page. Ketiga model ini merupakan model yang tergolong sederhana dilihat dari jumla konstanta pengeringan yang dimilikinya dibandingkan model lainnya. Dalam berbagai penelitian lapisan tipis, antara lain penelitian Ishak (2013), Oforkansi dan Oduola (2016), Zhiqiang et al.(2013), da Wilton et al. (2014), diantara ketiga model ini yang sering ditemukan mewakili perilaku penurunan kadar air sepanjang proses pengeringan adalah model Page.

Berdasarkan uraian tersebut di atas, penelitian ini diarahkan untuk melihat keakuratan model Page dalam memprediksi kadar air (moisture ratio) iles-iles yang berbentuk irisan (slice) selama proses pengeringan lapisan tipis.

\section{Tujuan dan Kegunaan}

Penelitian ini dimaksudkan untuk mengevaluasi keakuratan model Page dalam menduga moisture ratio umbi iles iles (Amorphophallus muelleri) yang berbentuk irisan selama proses pengeringan lapisan tipis.

Kegunaan dari penelitian pengeringan iles-iles yaitu menjadi referensi dan acuan dasar tentang pengeringan iles-iles yang selanjutnya dapat digunakan dalam kegiatankegiatan pengembangan bahan pangan alternatif.

\section{METODE PENELITIAN}

\section{Waktu dan Tempat}

Penelitian ini dilaksanakan pada bulan Januari hingga Februari 2020, bertempat di Laboratorium Processing, Program Studi 
Keteknikan Pertanian, Departemen Teknologi Pertanian, Fakultas Pertanian, Universitas Hasanuddin, Makassar.

\section{Alat dan Bahan}

Alat yang digunakan pada saat penelitian adalah alat pengering tipe batch dryer bantuan dari Australian Universities International Development Program, oven, timbangan digital (0,01 g), pisau, cutter, rang sampel, dan desikator.

Bahan yang digunakan adalah umbi iles-iles yang diperoleh dari Kabupaten Luwu Utara, Kecamatan Malangke, Desa Tolada.

\section{Perlakuan dan Parameter Pengamatan}

Penelitian ini menggunakan suhu pengeringan $45^{\circ} \mathrm{C}$ dan $55^{\circ} \mathrm{C}$ dengan ketebalan sampel ilesiles $1.0 \mathrm{~cm}$ dan $0.5 \mathrm{~cm}$. Kecepatan udara pengeringan digunakan sebesar $1.0 \mathrm{~m} / \mathrm{s}$. Parameter pengamatan adalah berat sampel selama proses pengeringan dan waktu pengeringan. Berat sampel digunakan dalam perhitungan kadar air bahan. Kadar air (Kabk) digunakan dalam perhitungan moisture ratio. Moistuer Ratio berikut waktu pengeringan $t$ menjadi input dalam penentuan konstanta pengeringan yang ada pada Model Page.

\section{Prosedur Penelitian}

Adapun prosedur penelitian iles-iles adalah sebagai berikut:

1. Persiapan Bahan

Bahan yang disiapkan dalam penelitian ini adalah iles-iles. Iles-iles dipisahkan dari bagian akar dan dicuci menggunakan air bersih. Kemudian iles-iles dipotong dengan ukuran $20 \times 20 \times 10 \mathrm{~mm}$ dan $20 \times 20 \times 5 \mathrm{~mm}$. Selanjutnya menimbang wadah sebelum berisi sampel dengan timbangan digital. Menyusun sampel kedalam wadah kemudian menimbang kembali wadah yang telah berisi sampel. Penimbangan dimaksudkan untuk mengetahui berat total sehingga berat wadah berisi sampel dapat lebih mudah dihitung dengan cara berat total dikurang dengan berat wadah.

\section{Prosedur Pengeringan}

Proses pengeringan pada penelitian dilakukan dengan menggunakan alat pengering tipe batch dryer dengan kecepatan udara pengering $1 \mathrm{~m} / \mathrm{s}$ dengan suhu $45^{\circ} \mathrm{C}$ dan $55^{\circ} \mathrm{C}$. Penimbangan sampel dilakukan setiap interval waktu 30 menit selama pengeringan hingga mencapai berat bahan konstan. Sampel yang telah mencapai berat konstan lalu dimasukkan ke oven selama 72 jam dengan suhu $105^{\circ} \mathrm{C}$. Setelah mencapai waktu 72 jam, bahan dikeluarkan dan ditimbang untuk mendapatkan berat kering bahan.

\section{Pengolahan Data}

Data yang diperoleh, berupa massa awal, massa selama pengeringan, dan massa akhir bahan. Selanjutnya diolah untuk memperoleh kadar air basis basah (Kabb), kadar air basis kering (Kabk), dan Moisture Ratio dengan menggunakan persamaan sebagai berikut :

\section{Kadar air basis basah (Kabb)}

$$
\mathrm{a}_{\mathrm{bb}}=\frac{\mathrm{Wt}-\mathrm{Wd}}{\mathrm{Wt}} \times 100 \%
$$

keterangan:

$$
\begin{aligned}
& \text { Kabb = kadar air basis basah }(\%) \\
& \mathrm{W}_{\mathrm{t}}=\text { berat bahan basah }(\text { gram }) \\
& \mathrm{W}_{\mathrm{d}}=\text { berat bahan kering }(\mathrm{gram})
\end{aligned}
$$

\section{Kadar air basis kering $\left(K a_{b k}\right)$}

$$
\mathrm{Ka}_{\mathrm{bk}}=\frac{\mathrm{Wt}-\mathrm{Wd}}{\mathrm{Wd}} \times 100 \%
$$

keterangan:

$$
\begin{aligned}
& \mathrm{Ka}_{\mathrm{bk}}=\text { kadar air basis kering }(\%) \\
& \mathrm{w}_{\mathrm{t}}=\text { berat total }(\text { gram }) \\
& \mathrm{w}_{\mathrm{d}}=\text { berat padatan }(\mathrm{gram})
\end{aligned}
$$

\section{Moisture Ratio}

$\mathrm{MR}=\frac{(\mathrm{KA}(\mathrm{bk}) \text { waktu }(\mathrm{t})-\mathrm{KA} \text { kesetimbangan }}{\text { (KA (bk)awal bahan }- \text { KA kesetimbangan }}$

\section{Mengevaluasi kinerja model page}

Model pengeringan lapisan tipis diperoleh dengan cara mencari nilai konstanta $\mathrm{k}$, dan $\mathrm{n}$ dari setiap bentuk eksponensial. Konstanta ditentukan menggunakan Solver Tools MS Excel. Solver Tool yang akan secara otomatis mencari nilai konstanta pada pengeringan model page yang dievaluasi. Input parameter yang dimasukkan ke solver adalah nilai Moisture Ratio (MR) dan waktu pengeringan (t). Keakuratan prediksi Model Page terhadap perilaku Moisture Ratio kemudian dilihat berdasarkan nilai nilai koefisien determinasi 
$\mathrm{R}^{2}$, dan nilai intercept dari grafik yang menghubungkan nilai MR prediksi model dengan nilai MR observasi. Dua parameter evaluasi lainnya adalah nilai Root Mean Squared Error (RMSE), dan Chi-Squared $\left(\mathrm{X}^{2}\right)$, yang masing-masing memiliki rumus seperti

berikut:

$$
\begin{aligned}
R M S E & =\frac{\sqrt{\sum\left(M R_{(\text {observed })}-M R_{(\text {predicted })}\right)^{2}}}{N} \\
\mathrm{X}^{2} & =\frac{\sum\left(M R_{(\text {observed })}-M R_{(\text {predicted })}\right)^{2}}{N-n}
\end{aligned}
$$

Keterangan:

$$
\begin{aligned}
& \text { "N" = jumlah pengamatan } \\
& \text { " } \mathrm{n} "=\text { jumlah parameter (konstanta } \\
& \text { pengeringan) yang terdapat dalam }
\end{aligned}
$$

\section{HASIL DAN PEMBAHASAN}

Hasil yang diperoleh selama penelitian ini seperti pola penurunan kadar air, pola penurunan moisture rasio, nilai konstanta pengeringan Model Page, dan evaluasi kinerja ModelPage disajikan berikut ini.

\section{Pola Penurunan Kadar Air}

Pola penurunan kadar air basis basah pada irisan iles-iles selama proses pengeringan disajikan pada Gambar 2 berikut:

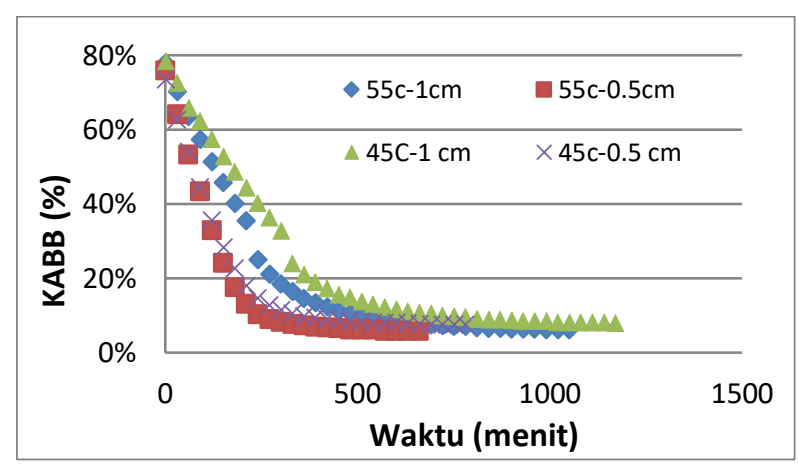

Gambar 2. Pola Penurunan Kadar Air Basis Basah

Dari gambar 2 di atas nampak bahwa pada suhu pengeringan $55^{\circ} \mathrm{C}$, irisan dengan ketebalan $1.0 \mathrm{~cm}$ memiliki kadar air awal sebesar $77,89 \%$ dan irisan $0,5 \mathrm{~cm}$ memiliki kadar air awal sebesar 75,82\%. Selama Proses pengeringan berlangsung. irisan dengan ketebalan $1.0 \mathrm{~cm}$ mengalami penurunan yang cepat dari menit ke 30 dengan kadar air 70,19\% hingga menit ke 360 dengan kadar air $14,52 \%$. Setelah itu penurunan kadar air menurun dan cenderung konstan. Pada irisan ketebal $0,5 \mathrm{~cm}$ terjadi penurunan yang cepat pada menit ke 30 dengan kadar air $64,05 \%$ hingga menit ke 270 dengan kadar air 8,97\%. Setelah periode tersebut tidak lagi terjadi penurunan yang cepat dan cenderung melambat.

Seperti dapat dilihat pada Gambar 3, pola yang sama terjadi pada suhu pengeringan $45{ }^{\circ} \mathrm{C}$, irisan dengan ketebalan $1.0 \mathrm{~cm}$ memiliki kadar air awal sebesar 78,42\% dan irisan $0,5 \mathrm{~cm}$ memiliki kadar air awal sebesar $73,57 \%$. Selama Proses pengeringan berlangsung, irisan dengan ketebalan $1.0 \mathrm{~cm}$ mengalami penurunan yang cepat pada menit ke 30 dengan kadar air $72.51 \%$ hingga menit ke 450 dengan kadar air 15,56\%. Setelah itu penurunan kadar air menurun dan cenderung konstan. Pada irisan ketebal $0,5 \mathrm{~cm}$ terjadi penurunan yang cepat pada menit ke 30 dengan kadar air 62,62\% hingga menit ke 270 dengan kadar air $12,72 \%$. Setelah periode tersebut tidak lagi terjadi penurunan yang cepat dan cenderung melambat.

Pada Gambar 3 dapat dilihat pola penurunan kadar air basis kering pada irisan iles-iles.

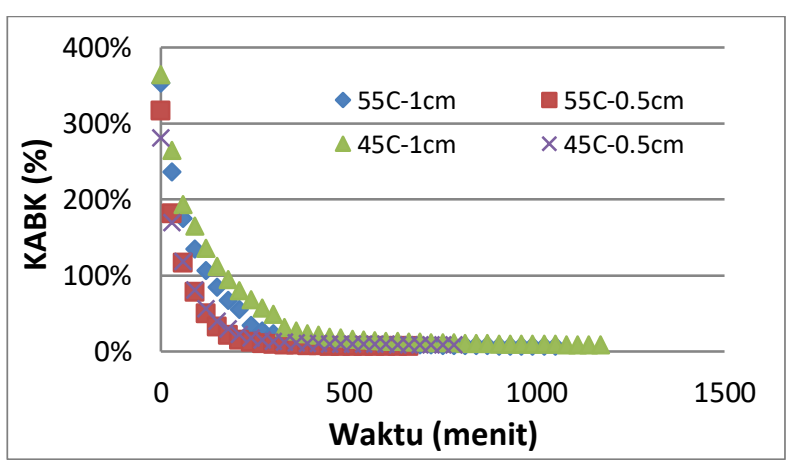

Gambar 3. Pola Penurunan Kadar Air Basis Kering

Pada suhu pengeringan $55^{\circ} \mathrm{C}$, irisan dengan ketebalan $1.0 \mathrm{~cm}$ memiliki kadar air awal basis kering sebesar $353 \%$ dan irisan 0,5 $\mathrm{cm}$ memiliki kadar air awal basis kering sebesar $316 \%$. Selama Proses pengeringan berlangsung, irisan dengan ketebalan $1.0 \mathrm{~cm}$ mengalami penurunan yang cepat pada menit 
ke 30 dengan kadar air basis kering 236\% hingga menit ke 420 dengan kadar air basis kering14\%. Setelah itu penurunan kadar air menurun dan cenderung konstan. Pada irisan ketebal $0,5 \mathrm{~cm}$ terjadi penurunan yang cepat pada menit ke 30 dengan kadar air basis kering 181\% hingga menit 270 dengan kadar air basis kering $10 \%$. Setelah menit tersebut tidak lagi terjadi penurunan yang cepat dan cenderung melambat.

Pada suhu pengeringan $45{ }^{\circ} \mathrm{C}$, irisan dengan ketebalan $1.0 \mathrm{~cm}$ memiliki kadar air awal basis kering sebesar $364 \%$ dan irisan 0,5 $\mathrm{cm}$ memiliki kadar air awal sebesar $280 \%$. Selama Proses pengeringan berlangsung, irisan dengan ketebalan $1.0 \mathrm{~cm}$ mengalami penurunan yang cepat pada menit ke 30 dengan kadar air 264\% hingga menit ke 450 dengan kadar air 18\%. Setelah itu penurunan kadar air menurun dan cenderung konstan. Pada irisan $0,5 \mathrm{~cm}$ terjadi penurunan yang cepat pada menit ke 30 dengan kadar air 169\% hingga menit ke 300 dengan kadar air $13 \%$.

Penurunan kadar air irisan iles-iles pada awal pengeringan cukup besar kemudian turun secara perlahan-lahan. Hal tersebut diakibatkan oleh massa air yang terdapat dipermukaan bahan yang menyebabkan penurunan kadar air yang cepat. Pada saat kadar air mendekati kadar air kesetimbangan, penurunan kadar air semakin lambat karena massa air yang ada dipermukaan bahan semakin menipis sehingga terjadi proses difusi. Sehingga dapat dikatakan bahwa semakin tinggi suhu alat pengering, maka waktu pengeringan yang diperlukan semakin cepat. Semakin besar perbedaan suhu antara pemanas dengan bahan pangan maka semakin cepat pula penguapan air dari bahan pangan. Hal tersebut sesuai dengan Taib (1998) menyatakan bahwa tinggi suhu dan kecepatan aliran udara selama sangatlah berpengaruh selama pengeringan, dimana semakin tinggi suhu dan kecepatan aliran udara, maka semakin cepat pula pengeringan terjadi, sama dengan semakin rendah suhu dan kecepatan udara maka semakin lambat pula proses pengeringan.
Ketebalan irisan juga sangat berpengaruh terhadap pola penurunan kadar air dimana semakin tebal irisan tanaman iles-iles maka semakin lama laju penurunan kadar airnya, dan semakin tipis irisan tanaman iles-iles maka semakin cepat laju penurunan kadar airnya. Hal ini sejalan dengan pendapat irawan (2011), bahwa luas permukaan bahan sangatlah mempengaruhi pengeringan, salah satunya dengan memperbesar luas permukaan bahan dengan cara diiris tipis.

\section{Pola Penurunan Moisture Rasio (MR)}

Pemilihan karateristik pada pengeringan dapat diperhatikan dengan menggunakan model selama pengeringan. Nilai pada Moisture Ratio(MR), memiliki peranan penting. Selama proses pengeringan, terjadi penurunan nilai MR. pada Gambar 5 dapat dilihat penurunan Moisture Ratio sejalan dengan penurunan kadar air basis kering. Hai ini di karenakan perubahan nilai Moisture Ratio dihitung dengan acuan kadar air basis kering. Pola ini selanjutnya digunakan menghitung konstanta pengeringan pada model Page.

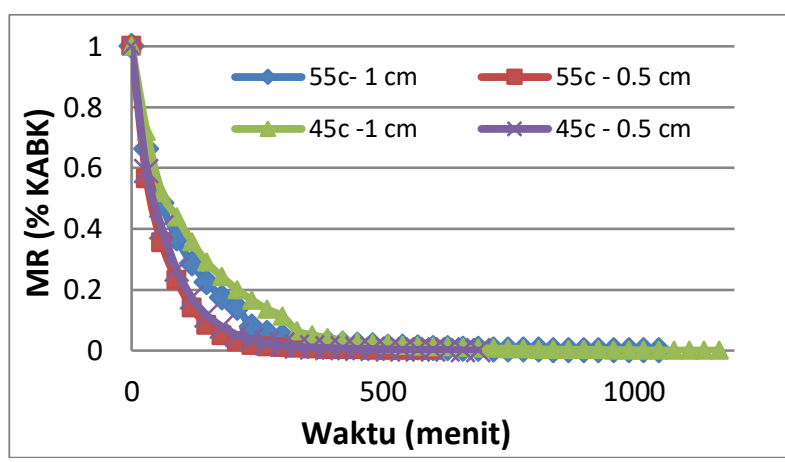

Gambar 4. Grafik Pola Penurunan Moisture Ratio (MR) terhadap KABK

\section{Analisis Nilai Konstanta Persamaan Page}

Konstanta pengeringan $\mathrm{k}$ dan $\mathrm{n}$ yang terdapat pada Model Page dapat dilihat dengan menggunakan Solver Tools MS Excel. Solver Tool. Software ini sdengaotomatis menilai konstanta pada pengeringan yang dievaluasi. Input parameter yang dimasukkan ke software adalah nilai Moisture Ratio (MR) dan waktu pengeringan (t). Hasil perhitungannya disajikan pada Tabel 1 berikut: 
Tabel 1. Nilai $\mathrm{k}$ dan $\mathrm{n}$ Model Page untuk berbagai perlakuan pengeringan lapisan tipis iles-iles.

\begin{tabular}{|c|c|c|c|c|c|c|}
\hline $\mathbf{T}$ & $\begin{array}{c}\text { Keteb } \\
\text { alan }\end{array}$ & $\mathbf{K}$ & $\mathbf{n}$ & $\mathbf{R}^{2}$ & $X^{2}$ & $\begin{array}{c}\text { RMS } \\
\text { E }\end{array}$ \\
\hline \multirow{2}{*}{$55^{\circ}$} & $1 \mathrm{~cm}$ & 0.713 & 0.853 & 0.998 & $\begin{array}{l}5,608 \\
\times 10^{-5}\end{array}$ & 0.007 \\
\hline & 0,5 & 1.052 & 0.916 & 0.999 & $\begin{array}{r}2,273 \\
\times 10^{-5} \\
\end{array}$ & 0.004 \\
\hline \multirow{2}{*}{$45^{\circ}$} & $1 \mathrm{~cm}$ & 0.590 & 0.841 & 0.997 & $\begin{array}{c}1,08 \times \\
10^{-5}\end{array}$ & 0.010 \\
\hline & 0,5 & 0.940 & 0.893 & 0.999 & $\begin{array}{l}2,129 \\
\times 10^{-5}\end{array}$ & 0.004 \\
\hline \multicolumn{4}{|c|}{ Nilai rata-rata } & 0,998 & $\begin{array}{l}5.202 \\
\times 10^{-5}\end{array}$ & 0.006 \\
\hline
\end{tabular}

Pada tabel 1 diatas dapat dilihat bahwa nilai $\mathrm{R}^{2}$ memiliki nilai yang tinggi selama pengeringan. Nilai yang didapatkan mendekati dengan nilai 1. Sehingga dapat dikatakan bahwa model page adalah model yang dapat digunakan untuk pengeringan tanaman iles-iles sesuai dengan pendapat Togrul (2004) yang menyatakan bahwa model page menggambarkan nilai koefisien korelasi $\left(\mathrm{R}^{2}\right)$. Nilai RMSE dan $\mathrm{X}^{2}$ yang sangat kecil juga menggambarkan bahwa Model Page dengan konstanta $\mathrm{k}$ dan $\mathrm{n}$ yang diperoleh cukup baik dalam memprediksi nilai moisture ratio iles-iles.

\section{Evaluasi Kinerja Model Page}

Untuk lebih menguatkan kesimpulan bahwa Model Page dengan konstanta yang diperoleh di atas cukup baik dalam memprediksi MR iles-iles, nilai prediksi MR dihubungkan dengan nilai MR observasi (hasil perhitungan berdasarkan data pengamatan) dalam suatu hubungan garis linear tanpa intercept seperti disajika Gambar 5, 6, 7 dan 8

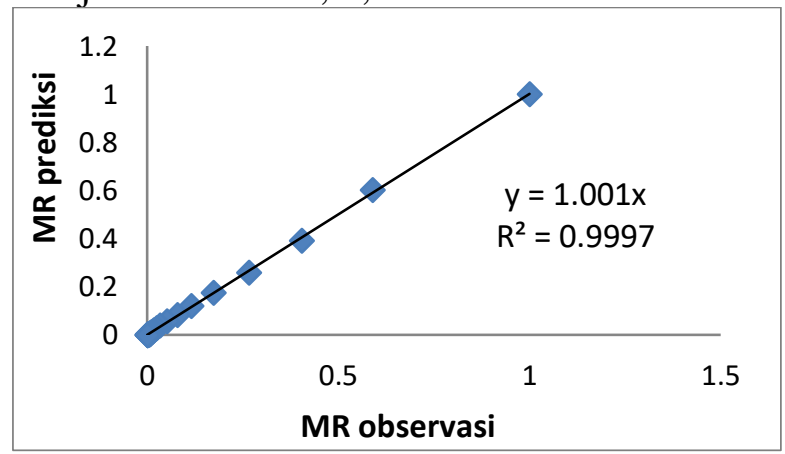

Gambar 5. Grafik Hubungan Model Page dengan Data Pengamatan untuk Suhu $45^{\circ} \mathrm{C}$ dan ketebalan $0.5 \mathrm{~cm}$

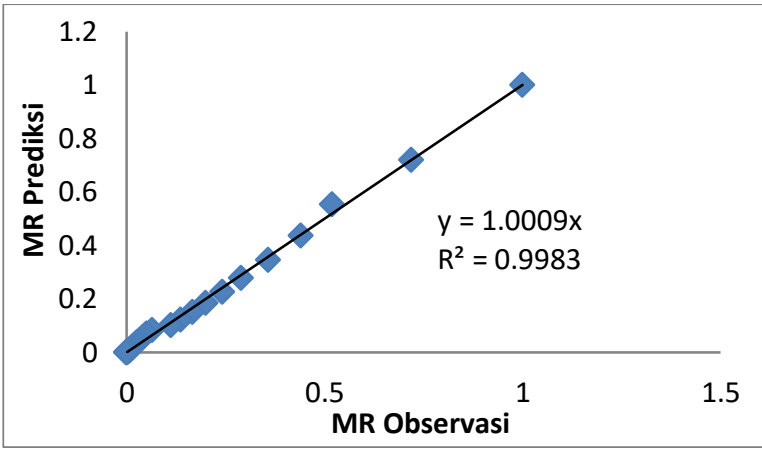

Gambar 6. Grafik Hubungan Model Page dengan Data Pengamatan untuk Suhu $45^{\circ} \mathrm{C}$ dan ketebalan $1 \mathrm{~cm}$.

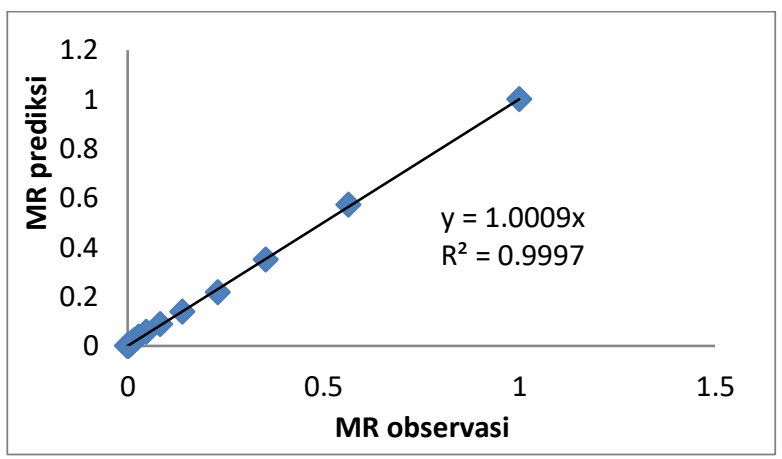

Gambar 7. Grafik Hubungan Model Page dengan Data Pengamatan untuk Suhu $55^{\circ} \mathrm{C}$ dan ketebalan $0.5 \mathrm{~cm}$.

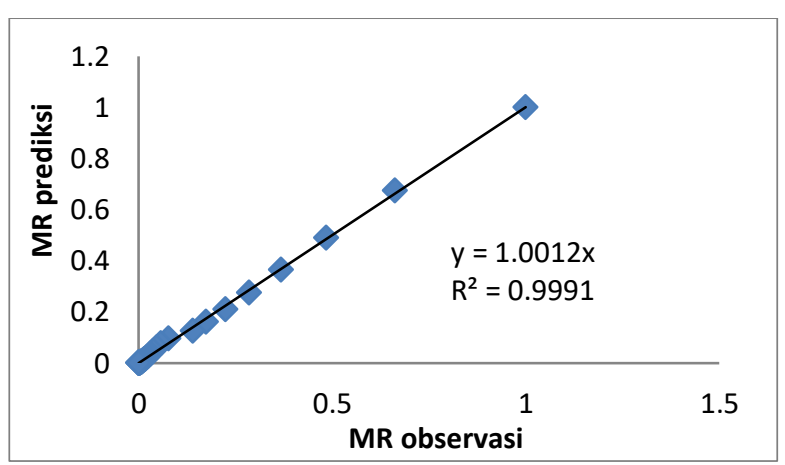

Gambar 8. Grafik Hubungan Model Page dengan Data Pengamatan untuk Suhu $55^{\circ} \mathrm{C}$ dan ketebalan $1 \mathrm{~cm}$.

Dari ke empat gambar di atas dapat dilihat bahwa "slope" dari persamaan linear yang diperoleh keempatnya sangat dekat dengan nilai " 1.0 " dengan nilai $\mathrm{R}^{2}$ juga mendekati "1.0". Hal ini merupakan indikasi kuat bahwa nilai prediksi MR sangat dekat dengan nilai observasi MR. Artinya, prediksi Model Page cukup baik. Selain grafik diatas, nilai $\mathrm{R}^{2}$, Chi-Squared, dan RMSE juga diperbandingkan (dengan melihat selisih) dengan beberapa hasil penelitian terdahulu 
seperti disajikan pada Tabel 1, yang ringkasannya disajikan pada Tabel 2 berikut. Hasil perbandingannya jelas menunjukkan bahwa selisih nilai dari ketiga parameter yang diperbandingkan sangat kecil. Oleh karena itu kesimpulan bahwa Model Page cukup akurat dalam memprediksi nilai MR iles-iles semakin kuat.

Tabel 2. Selisih nilai R2, Chi-squared, dan RMSE antara penelitian terdahulu dengan hasil penelitian pada skripsi ini.

\begin{tabular}{|c|c|c|c|c|}
\hline \multirow{2}{*}{ No } & \multirow{2}{*}{ Judul Artikel } & \multicolumn{3}{|c|}{$\begin{array}{c}\text { Selisih Nilai dengan Model } \\
\text { Page Hasil Penelitian }\end{array}$} \\
\hline & & $\mathbf{R}^{2}$ & $\begin{array}{l}\text { Chi- } \\
\text { Squared }\end{array}$ & RMSE \\
\hline 1 & $\begin{array}{l}\text { Mathematical } \\
\text { Model of Thin- } \\
\text { Layer Drying } \\
\text { Process in a } \\
\text { Plantain Sample, } \\
\text { (Oforkansi, B.C, } \\
\text { Oduola, M.K, } \\
\text { 2016) }\end{array}$ & $\begin{array}{c}- \\
0,00 \\
7\end{array}$ & 7,E-04 & 3,E-02 \\
\hline 2 & $\begin{array}{l}\text { Mathematicl } \\
\text { Modeling on Hot } \\
\text { Air Drying } \\
\text { of Thin Layer } \\
\text { Fresh Tilapia } \\
\text { Fillets(Zhiqiang } \\
\text { Guan, Xiuzhi } \\
\text { Wang } \\
\text { Min Li, } \\
\text { Xiaoqiang Jiang, } \\
\text { 2013) }\end{array}$ & $\begin{array}{c}- \\
0.00 \\
598 \\
07\end{array}$ & $\begin{array}{c}3.4798, \mathrm{E}- \\
04\end{array}$ & $\begin{array}{c}- \\
6.673 \mathrm{E}- \\
05\end{array}$ \\
\hline 3 & $\begin{array}{l}\text { Mathematical } \\
\text { models to } \\
\text { describe thin- } \\
\text { layer drying } \\
\text { and to determine } \\
\text { drying rate of } \\
\text { whole bananas } \\
\text { (Wilton Pereira } \\
\text { da Silva } \\
\text { Josivanda } \\
\text { Palmeira Gomes, } \\
\text { Cleide M.D.P.S. } \\
\text { e Silva, Fernando } \\
\text { J.A. } \\
\text { Gama,Josivanda } \\
\text { Palmeira Gomes, } \\
\text { 2014) }\end{array}$ & $\begin{array}{c}0.00 \\
081 \\
93\end{array}$ & 7,E-03 & \\
\hline 4 & $\begin{array}{l}\text { Modeling Drying } \\
\text { Kinetics of Fever } \\
\text { Leaves (Ocimum } \\
\text { Viride) in A } \\
\text { Convective Hot } \\
\text { Air Dryer } \\
\text { (Sobukola, }\end{array}$ & $\begin{array}{c}0.00 \\
091 \\
93\end{array}$ & & $-6, E-03$ \\
\hline
\end{tabular}

\begin{tabular}{|c|c|c|c|c|}
\hline \multirow{2}{*}{ No } & \multirow{2}{*}{ Judul Artikel } & \multicolumn{3}{|c|}{$\begin{array}{l}\text { Selisih Nilai dengan Model } \\
\text { Page Hasil Penelitian }\end{array}$} \\
\hline & & $\mathbf{R}^{2}$ & $\begin{array}{l}\text { Chi- } \\
\text { Squared }\end{array}$ & RMSE \\
\hline & $\begin{array}{l}\text { O.P.,and } \\
\text { Dairo,O.U, } \\
\text { 2007) }\end{array}$ & & & \\
\hline 5 & $\begin{array}{l}\text { Determina-tion } \\
\text { of Kinetic } \\
\text { Parameters for } \\
\text { Thin Layer } \\
\text { Drying of Corn } \\
\text { (Kenneth K. } \\
\text { Dagde, John T, } \\
\text { 2018) }\end{array}$ & $\begin{array}{c}0,00 \\
2\end{array}$ & & \\
\hline 6 & $\begin{array}{l}\text { Mathemat-ical } \\
\text { Modelling of } \\
\text { Thin Layer } \\
\text { Drying Kinetics } \\
\text { of Biodegradable } \\
\text { Pellets (Kulsum } \\
\text { Jan, Riar CS and } \\
\text { Saxena DC, } \\
\text { 2014) } \\
\end{array}$ & $\begin{array}{c}- \\
0.01 \\
598 \\
07\end{array}$ & $\begin{array}{l}4.295 \mathrm{E}- \\
02\end{array}$ & $3, \mathrm{E}-02$ \\
\hline 7 & $\begin{array}{l}\text { Thin Layer } \\
\text { Drying Kinetics } \\
\text { Of Kiwifruits } \\
\text { (var. Monty) } \\
\text { (Boris H, Babu } \\
\text { R, 2015) }\end{array}$ & $\begin{array}{c}- \\
0.06 \\
098 \\
07\end{array}$ & $\begin{array}{l}7.548 \mathrm{E}- \\
03\end{array}$ & $7, \mathrm{E}-02$ \\
\hline 8 & $\begin{array}{l}\text { Model } \\
\text { Pengering-an } \\
\text { Lapisan Tipis } \\
\text { Rebung Bambu } \\
\text { "Tabah" } \\
\text { (Gigantoc- } \\
\text { hloanigrociliata } \\
\text { KURZ) (Gede } \\
\text { A., P.K. Diah K, } \\
\text { IBP. Gunadnya, } \\
\text { Ni Luh Yulianti, } \\
\text { 2016) }\end{array}$ & $\begin{array}{c}0,00 \\
4\end{array}$ & & $-2, E-02$ \\
\hline 9 & $\begin{array}{l}\text { Model } \\
\text { Matematis } \\
\text { Pengeringan } \\
\text { Lapisan Tipis } \\
\text { Biji Kopi } \\
\text { Arabika (Coffeae } \\
\text { arabica) dan Biji } \\
\text { Kopi, Robusta } \\
\text { (Coffeae } \\
\text { cannephora) } \\
\text { (Dwi S, Djunaedi } \\
\text { M, dan } \\
\text { Mursalim, 2018) }\end{array}$ & $\begin{array}{c}0,00 \\
39\end{array}$ & & \\
\hline
\end{tabular}




\section{KESIMPULAN}

Kesimpulan yang diperoleh dari penelitian ini adalah sebagai berikut:

1. Berdasarkan grafik hubungan antara nilai prediksi dan nilai observasi moisture ratio yg menghasilkan persamaan regresi tanpa intersept dengan nilai $\mathrm{R}^{2}$ yang mendekati 0.1, maka Model Page yang diperoleh dianggap baik dalam melakukan prediksi moisture ratio umbi iles-iles.

2. Selisih nilai $\mathrm{R}^{2}$, Chi-squared, dan RMSE antara berbagai penelitian yg dilakukan terdahulu dengan penelitian ini yg relatif sangat kecil mengindikasikan bahwa kinerja Model Page pada penelitian ini juga cukup baik.

\section{DAFTAR PUSTAKA}

Boris Huirem, Babu Ram Shakya. 2015. Thin Layer Drying Kinetics Of Kiwifruits(var. Monty). International Journal of Science, Engineering and Technology Research.

Dwi Santoso, Djunaedi Muhidong, dan Mursalim. 2018. Model Matematis Pengeringan Lapisan TipisBiji Kopi Arabika (Coffeae arabica) dan Biji Kopi Robusta (Coffeae cannephora). Jurnal Teknologi Pertanian Andalas

Gede Arda, P.K. Diah Kencana, IBP. Gunadnya,Ni Luh Yulianti. 2016. Model Pengeringan Lapisan Tipis Rebung Bambu "Tabah" (Gigantochloa nigrociliata KURZ). Jurnal Rona Teknik Pertanian

Irawan, A. 2011. Pengeringan. Fakultas Teknik, Universitas Sultan Ageng Tirtayasa.

Irene. 2010. Mempelajari proses pengeringan glukomannan dari umbi iles-iles kuning (amorphophallus oncophyllus) dengan pengering semprot serta karakterisasi sifat fisikokimia dan reologinya. Skripsi Fakultas Teknologi Pertanian IPB: Bogor.

Ishak, 2013. Model Pengeringan Lapisan Tipis Cengkeh. Skripsi Fakultas Pertanian
Universitas Hasanuddin: Makassar.

Kenneth K. Dagde, John T. Iminabo. 2018. Determination of Kinetic Parametersfor Thin LayerDrying of Corn. International Research Journal of Advanced Engineering and Science.

Kulsum Jan, Riar CS and Saxena DC. 2014. Mathematical Modelling of Thin Layer Drying Kinetics of Biodegradable Pellets. Journal of Food Processing \& Technology

Sobukola, O.P., and Dairo, O.U. 2007. Modeling Drying Kinetics of Fever Leaves (Ocimum Viride) in A Convective Hot Air Dryer. Nigerian Food Journal

Taib, G.E., Gumbira, S., danWiraatmaj, S. 1988. Operasi Pengeringan Pada Pengelolahan Hasil Pertanian. PT. Mediyatama Sarana Prakasa: Jakarta.

Togrul, L. T. and Pehlivan, D. 2004. Modelling of Thin Layer Drying Kinetics of Some Fruits Under Open Air Sun Drying Process. Journal of Food Engineering. 65, 41-425.

Wilton Pereira da SilvaJosivanda Palmeira Gomes, Cleide M.D.P.S. e Silva, Fernando J.A. Gama,Josivanda Palmeira Gomes. 2014. Mathematical models to describe thin-layer drying. Journal of the Saudi Society of Agricultural Sciencesand to determine drying rate of whole bananas

Zhiqiang Guan, Xiuzhi Wang. Min Li, Xiaoqiang Jiang. 2013. Mathematical Modeling on Hot Air Drying of Thin Layer Fresh Tilapia Fillets. Polish Journal of Food and Nutrition sciences. 